\title{
PRELIMINARY SURVEY OF MICROALGAL SOIL CRUSTS IN A XERIC HABITATS (WADI-ARABA, EASTERN DESERT, EGYPT)
}

\author{
Ibraheem Borie Mohammad Ibraheem \\ Botany Dept., Fac. of Sci., Cairo Uni. (Beni-Suef Branch), \\ Beni-Suef, Egypt. \\ E-mail : Ibraheemii_org@yahoo.com
}

\begin{abstract}
Microalgal crusts of 12 desert plant communities distributed in 3 different stands in Wadi Araba and its tributaries (Eastern Desert, Egypt) were involved in the present investigation. Four sites were selected in each stand. Soil crusts and samples were collected during March 2003, and some physico-chemical characters of these samples in addition to some biotic and abiotic factors were determined. A total of 92 algal species were recorded in all sites. Of these, 48 species belong to Cyanophyta, 20 to Chlorophyta and 24 to Bacillariophyta. The data revealed that the quantity and quality of microbiological algal crusts were governed by the type of the flowering plants as well as by the edaphic factors and physico-chemical characters of the soil.
\end{abstract}

\section{Introduction}

Soil microorganisms commonly aggregate soil particles to form biological soil crusts, particularly in harsh environments where vascular plant distributions are patchy and water is limited (Johansen, 1993; Eldridge \& Greene, 1994 and Li et al., 2002). Biological crusts consisting of algae, cyanobacteria, lichens, fungi, bacteria, and mosses are common in habitats where water and nutrients are limited and vascular plant cover is discontinuous. Crusts alter soil factors including water availability, nutrient content, and erosion susceptibility, and thus are likely to directly and indirectly affect plants (Hawkes and Flechtner, 2002). Polysaccharides excreted by filamentous algae and cyanobacteria, along with the living organisms themselves, bind soil particles together into a single, consolidated layer to form a crust of the first few centimeters of surface soil (Baily, et al., 1973 and Campbell, et al., 1989). Microbiotic crust communities occur throughout arid and semi-arid regions of the world, and an interest in their role in nutrient cycling and the discovery of a rich microfauna and microflora have led to a growing number of ecological, physiological, and taxonomic studies (Kleiner and Harper, 1977; West, 1990; Lange \& et. al., 1992; St. Clair, et. al.,1993; Schlesinger \& et. al., 1996; Evans \& Johansen, 1999 and Lewis \& Flechtner, 2002). The earliest surveys of microbiotic crust organisms to include algae began in the 1960s with Cameron $(1960,1964)$, Shields \& Drouet (1962) and Friedmann \& et. al. (1967). These studies revealed a very small number of green algae from a given site. It is important to characterize the spatial 
distributions of organisms within crusts because of their biotic effects on both physical and chemical soil properties and their potential influence on vascular plants. A variety of biotic and abiotic factors may contribute to spatial heterogeneity of crust organisms (Hawkes and Flechtner, 2002).

The study of microscopic algal flora of desert soils habitats has been stimulated by the assumption that any extra-terrestrial life which might exist probably develops under similar extreme environmental conditions (Skujinš, 1984; Johansen, 1993 and Evans and Johansen, 1999). In Egypt, although the studies on algal flora of some cultivated soils together with edaphic and climatic factors were scarcely studied (El-Ayouty and Ayyad, 1972; Kobbia and ElBatanouny, 1975; Kobbia, 1983 \& 1985; Kobbia and Shabana, 1988 and Ahmed, 1994), these studies on desert habitat were unattainable by investigators. The present work therefore represents an attempt to bridge this gap in our knowledge. It is the first study aimed at surveying the algal populations inhabiting WadiAraba (Eastern Desert, Egypt), as well as the various environmental conditions affecting their distribution and density.

\section{Material and Methods \\ Experimental area:}

Wadi Araba is one of the largest drainage systems of the Eastern Desert, Egypt, which extends east of the Nile Valley to the Red sea coast. It lies in the northeast part of this desert, between Lat. $28^{\circ} 28^{\prime}-29^{\circ} 19^{\prime} \mathrm{N}$, Long $31^{\circ} 50^{\prime}-32^{\circ}$ $38^{\prime} \mathrm{E}$ (Fig. 1). The main stream of Wadi Araba is of an average of about 4-5 km wide and $85 \mathrm{~km}$ long, occupies the southern side of the vas bed (30 km wide) between the two Galala plateau at $80 \mathrm{~km}$ west Zafarana, then it turns after 25 $\mathrm{km}$ to the northern side (Abu Al-Izz, 1971). The downstream part of the wadi extends to the coastal plain of Suez Gulf, (Fig. 1). The most important tributaries of Wadi Araba are:

1. Wadi Abu-khodirate. It has about 4 effluents (range in length of 10-20 km) which join the main trunk of Wadi Araba at $85 \mathrm{~km}$ west of Zafarana and originates from SW outcrops of the North Galala.

2. Wadi Irkase. It is the longest tributary of Wadi Araba (40 km long). It originates from the NW escarpment of south Galala at $75 \mathrm{~km}$ west of Zafarana. Three stands were chosen for this study, each one with 4 sites. The first stand is the Main bed of Wadi Araba (only $10 \mathrm{~km}$ ), the second is Wadi Abu Khodirate (only $5 \mathrm{~km}$ ) and the one is Wadi Irkase (only $5 \mathrm{~km}$ ) Fig. 1.

\section{Meteorological Parameters.}

Egypt is characterized by a hot and almost rainless climate (Zahran and Willis, 1992). Wadi Araba locates in the hyper-aird zone with mild winter and hot summer (UNESCO, 1977 and Ayyad \& Ghabbour, 1986). Climatic aridity of the study area appears in the following parameters, which are obtained from Bir Araiyida station: 
* Temperature. Although the data recorded in Table 1 shows that, the annual mean temperature is $22.6^{\circ} \mathrm{C}$ which approximately suitable for algal growth, the microalgae of the study area were exposed for a great variability in temperature through the different seasons. The coldest month (January) has a mean temperature of $13.7^{\circ} \mathrm{C}$ while the hottest month (July) has a mean temperature of $31.4^{\circ} \mathrm{C}$ and a mean maximum temperature of $39.8^{\circ} \mathrm{C}$.

* Rainfall. Table 1, shows that, during year 2003 the mean annual rainfall is 3.4 $\mathrm{mm} /$ year and occurred during the months January and February (winter rainfall), where summer months are completely rainless.

* Relative humidity. It is much high. Table 1 , shows that, the most humid months (January and February) have a relative humidity reach to 72 and $65 \%$, respectively. The most arid months (June and July) have humidity of 38 and 33 \%respectively.

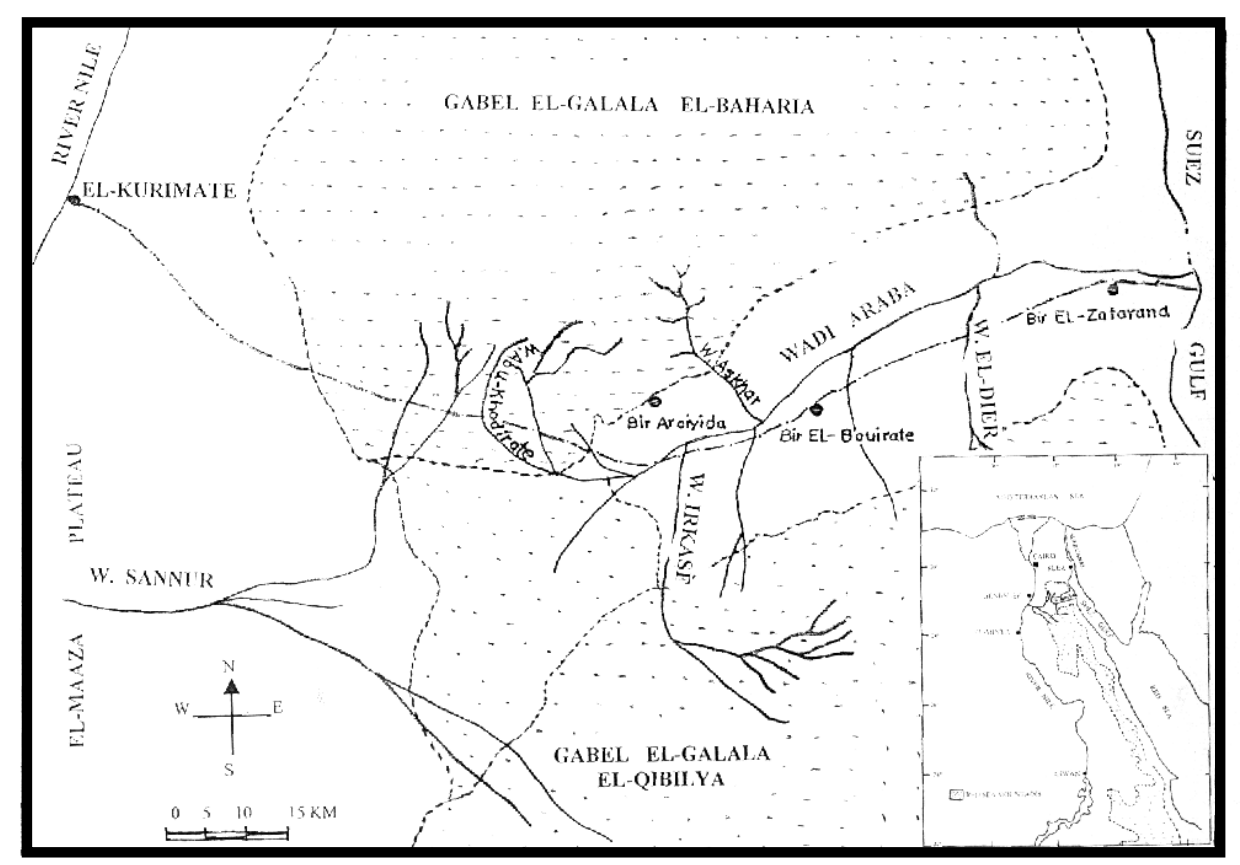

Fig. 1. Map of the study area

\section{Soil sampling and analyses.}

Each soil sample was a composite of 4 random samples taken from each site beside the dominant plant species $(0-5 \mathrm{~cm}$ depth) including crust and the subsurface soil layer, then kept in pre-sterilized plastic bags and transformed to laboratory for analysis (Loveday, 1974 and Salama and Kobbia, 1982). The samples were collected during March 2003. Soil texture analyses were carried out using method described in Soil Survey Staff (1972). Three major categories Egyptian J. of Phycol. Vol. 4(1), 2003 
of soil separates: sand $(2-0.05 \mathrm{~mm})$; silt $(0.05-0.002 \mathrm{~mm})$ and clay $(<0.002$ $\mathrm{mm}$ ) were recognized (Gee and Bauder, 1986). Particle size analysis is determined using sieves till $0.1 \mathrm{~mm}$ sieve diameter. Thin silt and clay are separated using pipette method (Piper, 1944). For chemical analyses, soil sample is sieved through $2 \mathrm{~mm}$ - sieve (Jackson, 1958 and Soil Survey Staff , 1972). Soil fraction $>2 \mathrm{~mm}$ are usually discarded in soil chemical analysis, these are not regarded as soil constituents, and are eventually rock fragments (Tan, 1996). Soil extracts at 1:5 were prepared for chemical analysis of soil. The $\mathrm{pH}$ was measured by $\mathrm{pH}$ meter Model (Fisher Scientific, Accumet ${ }^{\circledR}$, Model 800). Organic carbon is determined by Walkley-Black wet combustion method (Walkley, 1947 after Tan, 1996). Total carbonates were determined by rapid titration method (with $1 \mathrm{~N} \mathrm{HCL,}$ $1 \mathrm{~N} \mathrm{NaOH}$ and Ph.Ph indicator) according to Allen et al. (1974). Total soluble salts were determined by evaporation of the soil extract (1:5), it is expressed as a percent of total soil weight. The chlorides, soluble carbonates and bicarbonates are determined according the method described by Piper (1950). Soluble silicon contents of soil samples were determined by gravemetric method according to Standard Methods For The Examination of Water and Wastewater (1985).

Table 1. Average of monthly mean temperature, rainfall and relative humidity \% (records of Bir-Araiyida station) during year 2003.

\begin{tabular}{|c|c|c|c|c|c|}
\hline & \multicolumn{3}{|c|}{ Temperature $\left({ }^{\circ} \mathrm{C}\right)$} & \multirow{2}{*}{$\begin{array}{c}\text { Rainfall }(\mathrm{mm}) \\
\text { Average rainfall }\end{array}$} & \multirow{2}{*}{$\begin{array}{c}\text { Relative } \\
\text { humidity \% }\end{array}$} \\
\hline Month & Mean maximum & Mean minimum & Mean & & \\
\hline January & 20.4 & 7 & 13.7 & 2.1 & 72 \\
\hline February & 21.3 & 6.5 & 13.9 & 1.3 & 65 \\
\hline March & 28 & 13 & 20.5 & 0 & 52 \\
\hline April & 30.6 & 14 & 22.3 & 0 & 44 \\
\hline May & 35 & 18 & 26.5 & 0 & 40 \\
\hline June & 37 & 21 & 29 & 0 & 38 \\
\hline July & 39.8 & 23 & 31.4 & 0 & 33 \\
\hline August & 37 & 21.6 & 29.3 & 0 & 40 \\
\hline September & 34.3 & 20 & 27.2 & 0 & 42 \\
\hline October & 31 & 15.7 & 23.4 & 0 & 46 \\
\hline November & 27 & 11.8 & 19.4 & 0 & 52 \\
\hline December & 21 & 8.3 & 14.65 & 0 & 60 \\
\hline Average & 30.2 & 14.9 & 22.6 & 3.4 & 48.7 \\
\hline
\end{tabular}

Covering plant communities. The natural predominant covering plant communities in the study stands were recorded in Table (2). 
Table 2. Most common plant communities occurring in the investigated sites of Wadi Araba, Egypt (during March, 2003).

\begin{tabular}{|c|c|c|c|c|c|c|c|c|c|c|c|c|}
\hline \multirow{3}{*}{ Plant community } & \multicolumn{4}{|c|}{$\begin{array}{c}\text { Main-bed } \\
\text { of Wadi-Araba* }\end{array}$} & \multicolumn{4}{|c|}{$\begin{array}{l}\text { Wadi Abu- } \\
\text { Khodirate** }^{* *}\end{array}$} & \multicolumn{4}{|c|}{$\begin{array}{c}\text { Wadi- } \\
\text { Irkase*** }\end{array}$} \\
\hline & \multicolumn{4}{|c|}{ Site } & \multicolumn{4}{|c|}{ Site } & \multicolumn{4}{|c|}{ Site } \\
\hline & 1 & 2 & 3 & 4 & 1 & 2 & 3 & 4 & 1 & 2 & 3 & 4 \\
\hline $\begin{array}{l}\text { 1.Acacia tortilis (Forssk) Hayne subsp. Tortilis } \\
\text { Gertreue Darstell. Gew. } 10: \text { tab. } 31 \text { (1827): El- } \\
\text { Hadidi \& Fayed :78 (1994 / 95) }\end{array}$ & & & & & + & & & & & & & \\
\hline $\begin{array}{l}\text { 2. Hammada elegans (Bunge) Boc.In Novosite } \\
\text { Sist. Vyso. Rast. 1: } 362 \text { (1964), Boulos: } 26 \text { (1995). }\end{array}$ & & & + & & & & & & + & & & \\
\hline $\begin{array}{l}\text { 3. Pennisetum divisum (G.F. Gemel) Henrard, } \\
\text { Blumea 3:162 (1939), Boulos : } 204 \text { (1995). }\end{array}$ & & & & & & & & & & & + & \\
\hline $\begin{array}{l}\text { 4. Pulicaria crispa (Forssk.) Benth.ex D. Oliver in } \\
\text { Grant, Trans. Linn. Sos. London } 29 \text { : } 96 \text { (1873), } \\
\text { El-Hadidi \& Fayed :165 (1994 /95). }\end{array}$ & + & & & & & & & + & & + & & \\
\hline $\begin{array}{l}\text { 5. Retama raetam (Forssk.) Webb in Weeb \& } \\
\text { Benth., Hist. Nat. Canaries 3(2,2):56(1842), El- } \\
\text { Hadidi \& Fayed :58 (1994 / 95). }\end{array}$ & & & & & & & & & & & & + \\
\hline $\begin{array}{l}\text { 6. Zilla spinosa (Turra) Prantl in Engler \& Prantl, } \\
\text { Nat. Pflanzenfam. } 3(2): 175 \text { (1981), El-Hadidi \& } \\
\text { Fayed :49 (1994 / 95). }\end{array}$ & & + & & & & + & & & & & & \\
\hline $\begin{array}{l}\text { 7. Zilla spinosa (Turra) Prantl in Engler \& Prantl, } \\
\text { Nat. Pflanzenfam. 3(2):175(1981), El-Hadidi } \\
\text { \&Fayed : } 49 \text { (1995) / Euphorbia retusa Frossk., } \\
\text { Fl.Aegypt. - Arab.:93 (1775), El-Hadidi \& Fayed : } \\
90 \text { (1994 / 95). }\end{array}$ & & & & + & & & & & & & & \\
\hline $\begin{array}{l}\text { 8. Zilla spinosa (Turra) Prantl in Engler \& Prantl, } \\
\text { Nat. Pflanzenfam. } 3 \text { (2):175 (1981), El-Hadidi } \\
\text { \&Fayed : } 49 \text { (1994 / 95) / Launaea spinosa } \\
\text { (Forssk.) Schultz Bip.ex O. Kuntze, Revis.Gen.1 } \\
: 350(1891)) \text {, El-Hadidi \&Fayed :175 (1994/ 95). }\end{array}$ & & & & & & & + & & & & & \\
\hline
\end{tabular}

* Ten Kilometers within the bed of Wadi-Araba.

** Five Kilometers within Wadi Abu-Khodirate

*** Five Kilometers within Wadi-Irkase.

\section{Isolation and culturing of algae.}

Soil samples were taken by cores ( $5 \mathrm{~cm}$ diameter) from subsurface soil up to $5 \mathrm{~cm}$ around the roots of the most common plant species as described before. Cores of all materials were placed in pre-sterilized plastic bags and returned to the laboratory where $2.5 \mathrm{~g}$ aliquot of each wet sample was subsequently blended in $20 \mathrm{ml}$ dist. $\mathrm{H}_{2} \mathrm{O}$ for identification of the live cells. For the algal culturing, a method recommended by Jurgensen and Davey (1968) was applied. One gram of each soil sample was placed in $99 \mathrm{ml}$ of sterile water and then placed in a shaker for $15 \mathrm{~min}$. Five replicate Petri-dishes were inoculated each with $1 \mathrm{ml}$ of the appropriate dilution and $25 \mathrm{ml}$ of nutrient agar medium $\left(45^{\circ} \mathrm{C}\right)$ were added. Myers' $\mathrm{C}$ medium incubated at $35 \pm 1{ }^{\circ} \mathrm{C}$ was used for isolation of blue-green algae. For nitrogen-fixing species Allen's free-nitrogen media (Allen and Stainer, Egyptian J. of Phycol. Vol. 4(1), 2003 
1968) was applied. The eukaryotic algae were isolated in Bristol's medium (Nichols, 1973) at $20 \pm 1{ }^{\circ} \mathrm{C}$. All were inoculated on a $16 / 8 \mathrm{hr}$ light / dark cycle with a light intensity of 3500 to 4500 Luxmeter. The algal species were identified according to Prescott (1951,1969 \& 1978), Smith (1933 \& 1951$)$ and EL-Nayal (1935). Diatoms were cleaned and identified according to Riley (1967).

\section{Results}

The approach adopted in the present investigation was conducted to study the microalgal crusts inhabiting desert soils around the most common plant communities of Wadi Araba as well as the physico-chemical characters of its soils during March, 2003. It is evident from Table 3 that the granulometric analysis of soil showed that the percentage of gravel, coarse and fine sand, silt and clay fractions varied remarkably from one site to another. Higher percentage of coarse sand was revealed by site 1 (main bed of Wadi Araba) $(74.41 \%$ ) and site 4 (Wadi Abu-Khodirate) (50.8\%), while the maximum percentage of fine sand were found in site 4 and site 1 of Wadi-Irkase (72 and 62.8\%) followed by site 3 of the main bed of Wadi Araba (61.8\%). Also, the highest maximum percentages of very fine sand were represented by sites 2, 3 and 1 of Wadi Irkase $(27.3 ; 27$ and $22.85 \%)$. The highest amount of silt was observed in sites 2 and 3 of Wadi Irkas (2\%) and the lowest percentage was recorded in site 1 of the main bed of Wadi Araba (0.4 $\%$ ). On the other hand, higher clay percentages were a distinct character of site 3 ( Wadi Abu-Khodirate ) ( $3.06 \%$ ) and site 4 ( main bed of Wadi Araba) (3\%), whereas the least value was recorded for site 1 (main bed Wadi Araba) $(1.3 \%)$. The chemical characters of the investigated soil samples revealed that $\mathrm{pH}$ values were recorded to be always on the alkaline side and lied between 8 (site 1, Wadi Abu-Khodirate ) to 8.5 (site 1, main bed of Wadi Araba). In this respect, sites of the main bed of Wadi Araba recorded the highest $\mathrm{pH}$ values (see Table 3). Soil samples of Wadi Abu-khodirate and Wadi Irkase were characterized by lower contents of organic matter. On the other hand all soil samples of the main bed of Wadi Araba revealed relatively high organic matter contents. The data revealed also a variations in $\mathrm{CO}_{3}^{--}$content of all soil samples. However, the maximum percentages were contained in the soil samples of site 3 and 2 of Wadi AbuKhodirate (74.6 and $66.7 \%$, respectively) and the lowest value was observed for site 1 of the main bed of Wadi Araba (14\%). All soil samples seemed to be poor in their soluble salts and low values of $\mathrm{HCO}_{3}{ }^{-}$. On the other hand, $\mathrm{Cl}^{-}$ion content of soil sample contained in site 4 (the main bed of Wadi Araba) exceeded that of the other sites. Higher soluble silicon contents were recorded at site 1, ( the mainbed of Wadi-Araba) (39.35\%) followed by sites 4 and 2 (Wadi Abu-Khodirate) 20.87 and $20.63 \%$, respectively, whereas the lowest contents were recorded at all soil sampled from Wadi Irkase where it ranged from 2.28 to $8.36 \%$.

The most common algal divisions inhabiting the soil samples experimented with, being detected either by direct observation or by the culture method included the blue-greens (Cyanophyta), the greens (Chlorophyta) and diatoms (Bacillariophyta). Among the above taxa, the diatoms appeared to have 
the greatest abundance, where the other genera were more abundant by the culture methods. The data recorded approximately 92 species present (Table 4). Of these, 48 belong to Cyanophyta, 20 to Chlorophyta and 24 to Bacillariophyta. Cyanophyta frequently appeared constituting about $52.17 \%$ of the representative algal species of all soil sampled and there were predominant by the filamentous forms, Oscillatoria, Nostoc, Phormidium and Lyngbya. The lowest percentage of the representive species was recorded by Chlorophyta $(21.74 \%)$, where the most common representative species were the unicellular and colonial forms. The predominant genus was Scenedesmus. On the other hand, Bacillariophyta recorded a moderate percentage $(26.09 \%)$, where the most dominant genera were Navicula and Nitzschia.

In a comparison of habitats, all sites of the main bed of Wadi Araba showed the greatest number of species (168) representing $39.72 \%$ of all species recovered. As shown in Table 5 and Fig. 3, the highest number of species arranged by habitats were site 1 (the main bed of Wadi Araba), representing $11.24 \%>$ site 2 (the main bed of Wadi Araba), $10.54 \%>$ site 4 (the main bed of Wadi Araba), $9.34 \%>$ site 3 (the main bed of Wadi Araba) $8.67 \%>$ site 4 (Wadi Abu-Khodirate), $8.43 \%>$ site 1 (Wadi Irkase), $8.20 \%>$ site 3 (Wadi Irkase), $7.96 \%>$ site 2 (Wadi Irkase), $7.73 \%>$ site 2 (Wadi AbuKhodirate), $7.49 \%>$ site 1 (Wadi Abu-Khodirate), $7.26 \%>$ site 3 (Wadi AbuKhodirate) $6.56 \%>$ site 4 (Wadi Irkase), $6.09 \%$.

Ranking the algal divisions, Fig 4 showed that, Cyanophyta recorded the highest percentage of the total number of taxa $(47.31 \%)$, followed by bacillariophyta $(29.51 \%)$, while the lowest percentage was recorded by chlorophyta $(23.19 \%)$.

\section{Discussion}

It is evident that the quantity and quality of micro algal crusts were governed by the type of the flowering plants as well as by the edaphic factors and physico-chemical characters of the soil. This is well represented when noticing that the highest algal population were contained in the crust of Zilla spinosa in site 2 (main bed of Wadi Araba), followed by the crust of Pulicaria crispa inhabiting site 1 of the main bed of Wadi Araba. Macro-vegetation might be affecting the life of soil algae of the studied sites, a phenomenon that was confirmed by Lund (1967) and Salama \& Kobbia (1982). 
Ibraheem B.M. Ibraheem

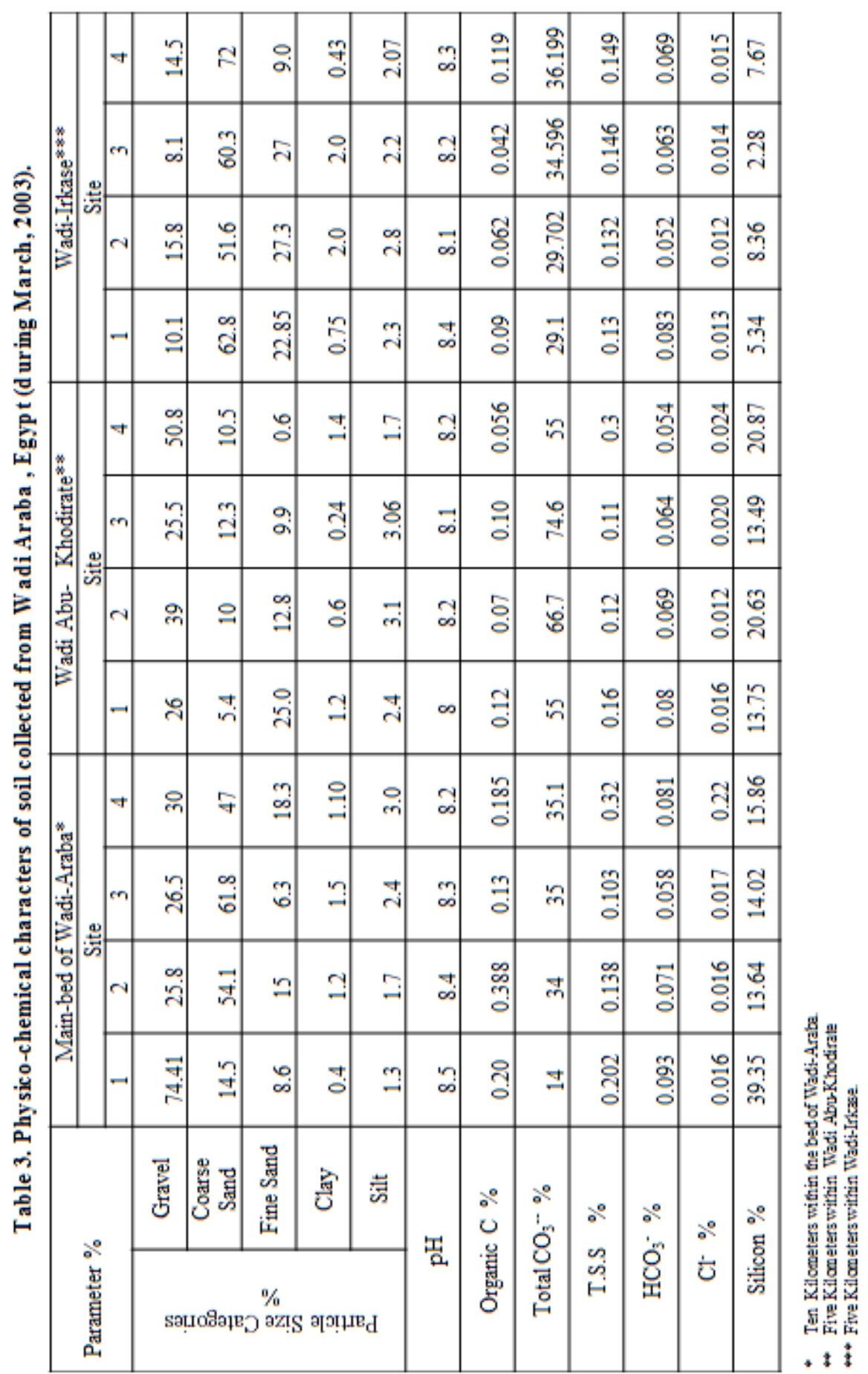


Table 4. Most common microalgal crusts occurring on the investigated stands of Wadi Araba, Egypt (during March, 2003).

\begin{tabular}{|c|c|c|c|c|c|c|c|c|c|c|c|c|}
\hline \multirow{3}{*}{ Microalgae } & \multirow{2}{*}{\multicolumn{4}{|c|}{$\begin{array}{c}\begin{array}{c}\text { Main-bed } \\
\text { of Wadi-Araba* }\end{array} \\
\text { Site }\end{array}$}} & \multirow{2}{*}{\multicolumn{4}{|c|}{$\begin{array}{c}\begin{array}{c}\text { Wadi Abu- } \\
\text { Khodirate** }\end{array} \\
\text { Site }\end{array}$}} & \multicolumn{4}{|c|}{ Wadi-Irkase ${ }^{* * *}$} \\
\hline & & & & & & & & & & & & \\
\hline & 1 & 2 & 3 & 4 & 1 & 2 & 3 & 4 & 1 & 2 & 3 & 4 \\
\hline Cyanophyta & & & & & & & & & & & & \\
\hline Anabaena aequalis Borge & + & + & - & + & + & - & + & + & - & + & - & + \\
\hline A. circinalis Rabenhorst & + & + & + & - & - & - & - & + & + & - & + & + \\
\hline A. solitria klebahn. & - & + & + & + & + & + & + & - & - & - & + & - \\
\hline A. variabilis küetz. & - & - & - & - & - & + & - & - & + & + & - & - \\
\hline Aphanothece gelatinosa (Henn.) Lemm. & + & + & + & + & - & - & - & - & - & + & - & - \\
\hline A. nidulans $\mathrm{P}$. Richter & - & - & - & + & - & - & - & - & - & - & + & - \\
\hline Calothrix parietina (Nageli) Thirret. & + & + & - & - & - & - & - & - & + & - & - & - \\
\hline C. scopularum Weberet Mohr. & - & - & - & + & - & - & - & + & - & - & - & - \\
\hline C. spp. & - & + & - & - & + & - & - & - & - & - & - & - \\
\hline Chroococcus hansgiri & + & + & - & - & - & - & - & + & - & - & - & + \\
\hline C. minor (kủetz.) Naegeli & - & - & - & - & - & + & - & - & - & - & - & - \\
\hline C. rufescens & + & + & - & + & + & - & - & - & - & - & - & - \\
\hline C. turgidus (küetz.) Naegeli & - & - & - & - & + & - & - & - & - & + & + & - \\
\hline C. varius A.Br. & + & + & + & - & - & - & - & - & + & - & - & - \\
\hline Gloeocapsa aeruginosa (Carm.) kủetzing & + & - & + & - & - & - & + & - & - & + & - & + \\
\hline G. rupestris kủetzing & - & + & + & - & - & - & - & + & - & - & + & - \\
\hline Lyngbya birgei G.M. Smith & + & - & - & + & - & - & - & - & + & - & - & - \\
\hline L. hieronymusii Lemm. & - & - & + & - & - & - & + & - & - & - & - & - \\
\hline L. limnetica Lemm. & + & + & + & - & + & + & - & - & - & - & - & - \\
\hline L. major Meneghini & + & + & + & + & - & - & - & - & - & - & - & - \\
\hline L. versicolor (Wartmann) Gomont & - & + & - & + & - & - & - & - & - & - & - & - \\
\hline Microcoleus vaginatus & + & - & - & - & - & - & - & - & - & - & - & - \\
\hline Nodularia spumigena Mertens & - & + & + & + & - & - & + & - & - & - & - & - \\
\hline Nostoc calcicola & + & + & - & - & + & - & + & + & - & - & - & + \\
\hline N. commune Vaucher & + & + & + & + & - & - & - & + & + & - & + & - \\
\hline N. linckia (Roth) Bornet \& Thuret & + & - & + & + & - & + & - & - & - & + & - & + \\
\hline N. muscorum C. A. Agardh & - & + & - & + & + & - & - & - & + & - & - & + \\
\hline N. punctiforme (kủetz.) Hariot & + & - & + & + & - & + & + & + & + & - & + & - \\
\hline N. sphaericum Vaucher & - & + & + & - & + & + & - & - & - & + & - & - \\
\hline N. verrucosum Vaucher & + & - & + & - & - & - & - & - & + & + & + & + \\
\hline Oscillatoria acutissima kufferath & + & + & - & - & + & - & + & + & - & - & + & - \\
\hline O. agardhii Gomont & + & + & + & + & - & - & - & - & - & - & + & - \\
\hline$O$. boryang & - & - & - & + & - & + & - & + & - & + & - & + \\
\hline O. breris (küetz.) Gomont. & - & + & + & + & - & - & + & - & + & - & - & - \\
\hline O. formosa Bory & - & + & - & - & - & + & + & - & + & - & + & + \\
\hline O. limnetica Lemm. & + & + & - & + & + & - & - & + & - & - & - & - \\
\hline
\end{tabular}

* Ten Kilometers within the bed of Wadi-Araba.

** Five Kilometers within Wadi Abu-Khodirate

*** Five Kilometers within Wadi-Irkase. 
Table 4. Continue

\begin{tabular}{|c|c|c|c|c|c|c|c|c|c|c|c|c|}
\hline \multirow{3}{*}{ Microalgae } & \multirow{2}{*}{\multicolumn{4}{|c|}{$\begin{array}{c}\begin{array}{c}\text { Main-bed } \\
\text { of Wadi-Araba* }\end{array} \\
\text { Site }\end{array}$}} & \multirow{2}{*}{\multicolumn{4}{|c|}{$\begin{array}{c}\begin{array}{c}\text { Wadi Abu- } \\
\text { Khodirate** }\end{array} \\
\text { Site }\end{array}$}} & \multicolumn{2}{|c|}{ Wadi- } & \multicolumn{2}{|c|}{ Irkase ${ }^{* * *}$} \\
\hline & & & & & & & & & \multicolumn{4}{|c|}{ Site } \\
\hline & 1 & 2 & 3 & 4 & 1 & 2 & 3 & 4 & 1 & 2 & 3 & 4 \\
\hline O. limosa (Roth) C.A. Agardh & & & & & & & & & & & & \\
\hline O. lutea & - & + & - & + & - & - & - & + & + & - & - & - \\
\hline O. Intea & + & - & - & + & - & + & + & - & - & - & - & - \\
\hline O. tenuis C.A. Agardh & - & + & + & - & - & - & - & - & - & - & + & - \\
\hline Phormidium inundatum kủetzing & - & - & - & - & - & - & + & - & - & + & - & + \\
\hline P. minnesotene & + & + & 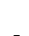 & 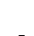 & + & 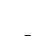 & $\mathbf{T}$ & 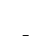 & . & - & 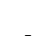 & T \\
\hline P. molle (kủetz.) Gomont. & $T^{\prime}$ & + & + & + & + & . & + & - & + & - & - & - \\
\hline P. retzii (C.A. Ag.) Gomont & + & + & + & + & 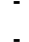 & - & + & + & + & - & - & - \\
\hline P. tenue (Menegh.) Gomont & + & + & + & 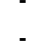 & 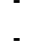 & - & 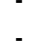 & + & + & + & 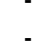 & \\
\hline Scytonema archangelii Bornet \& & & + & + & - & - & - & - & - & + & + & - & \\
\hline Flahault & - & - & - & + & - & + & - & - & - & - & - & - \\
\hline S. hofmanni & - & - & - & + & - & - & + & - & - & - & + & - \\
\hline Synechococcus aeruginosus & + & - & - & - & + & - & - & - & - & - & - & - \\
\hline Tolypothrix tenuis & + & - & - & - & - & - & - & + & - & - & - & + \\
\hline \multicolumn{13}{|l|}{ Chlorophyta } \\
\hline Ankistrodesmus falcatus (Cord) Ralfs & - & - & + & + & - & - & - & - & + & - & - & + \\
\hline A. alcatus var. acicularis (A. Braum) & & & & & & & & & & & & \\
\hline G.S. West & + & - & + & - & + & - & - & - & - & - & + & + \\
\hline $\begin{array}{l}\text { A. falcatus var. mirabilis ( West \& } \\
\text { West) G.S. West }\end{array}$ & & & & & & & & & & & & \\
\hline & - & - & + & - & - & + & - & - & + & + & - & - \\
\hline Chlamydomonas gloeophila & - & - & - & + & - & - & - & - & - & - & + & + \\
\hline C. lateralis & - & - & - & - & + & + & - & - & - & + & - & - \\
\hline C. spp. & - & - & - & - & - & + & + & - & + & - & - & - \\
\hline Chlorella protothecotdes krug. & + & - & + & + & + & + & + & + & + & + & + & - \\
\hline C. vulgaris Beyerinck. & + & + & - & + & + & + & + & + & + & + & + & - \\
\hline Chlorococcum humicola (Naeg.) Raben. & - & - & - & + & - & - & - & - & - & - & + & - \\
\hline C. brecispinosa & - & + & - & - & + & - & + & + & - & + & - & - \\
\hline $\begin{array}{l}\text { Dactylococcopsis rhaphidioides } \\
\text { Hansgirg }\end{array}$ & - & - & - & + & - & - & + & - & - & - & - & - \\
\hline Hapalosiphon pumilus (kủetz.) kirchner & & - & + & - & + & - & + & - & - & + & + & - \\
\hline Nuriella spp. & & - & - & - & + & - & - & + & - & + & - & - \\
\hline Palmella miniata & - & - & - & - & - & + & - & - & - & - & + & - \\
\hline Pandorina morum (Muell.)Bory & 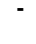 & - & + & + & - & + & - & + & - & - & + & - \\
\hline Scenedesmus acuminatus (Lag.) Chodat & & - & - & + & + & - & - & + & + & + & + & - \\
\hline S. armatus (Chod.) G. M. Smith & & + & - & + & - & + & + & + & + & - & - & - \\
\hline S. bijugatus (Turp.) Lag. & + & - & - & + & + & + & + & - & - & + & + & - \\
\hline S. dimorphus (Turp.) küetzing & + & + & + & - & - & - & + & + & + & + & + & + \\
\hline S. obliquse (Turp.) küetzing & - & - & + & - & + & - & - & - & - & + & + & + \\
\hline
\end{tabular}

* Ten Kilometers within the bed of Wadi-Araba.

** Five Kilometers within Wadi Abu-Khodirate

*** Five Kilometers within Wadi-Irkase. 
Table 4. Continue

\begin{tabular}{|c|c|c|c|c|c|c|c|c|c|c|c|c|}
\hline \multirow{3}{*}{ Microalgae } & \multirow{2}{*}{\multicolumn{4}{|c|}{$\begin{array}{c}\begin{array}{c}\text { Main-bed } \\
\text { of Wadi-Araba* }\end{array} \\
\text { Site }\end{array}$}} & \multirow{2}{*}{\multicolumn{4}{|c|}{$\begin{array}{c}\begin{array}{c}\text { Wadi Abu- } \\
\text { Khodirate** }\end{array} \\
\text { Site }\end{array}$}} & \multicolumn{4}{|c|}{ Wadi-Irkase ${ }^{* * *}$} \\
\hline & & & & & & & & & & & & \\
\hline & 1 & 2 & 3 & 4 & 1 & 2 & 3 & 4 & 1 & 2 & 3 & 4 \\
\hline \multicolumn{13}{|l|}{ Bacillariophyta } \\
\hline Achnanthes linearis (W.Sm.) Grun & + & - & - & - & - & - & + & + & + & - & - & - \\
\hline Bacillaria paradoxa & - & + & + & + & - & - & - & - & - & - & - & - \\
\hline Cyclotella comnta (Ehrenb.)Kutz. & + & + & - & + & + & - & - & - & + & - & - & + \\
\hline C. kuetzingiana Thwaites. & + & + & + & - & + & - & - & + & + & - & - & + \\
\hline Cymbella affins küetz. & - & - & - & - & - & - & - & + & - & + & - & - \\
\hline Gomphonema parvulum Kutz. & + & - & - & + & - & - & - & + & - & + & - & - \\
\hline Melosira granulata (Her.) Ralfs & - & - & - & + & - & + & - & + & - & + & + & - \\
\hline M. roseana & + & + & - & - & - & + & - & - & - & - & + & + \\
\hline Navicula asellus & + & + & + & - & - & + & - & + & + & - & - & - \\
\hline$N$. contenta & + & + & + & - & + & - & - & - & + & - & - & - \\
\hline N. cryptocephala Kutz. & + & + & + & + & + & - & - & + & + & + & - & - \\
\hline N. exigua (Gregory) Muller. & - & + & - & - & - & + & - & + & - & - & - & + \\
\hline N. mutica Kuetz. & + & + & - & - & - & + & + & - & - & + & + & - \\
\hline N. paramutica & + & - & - & - & - & + & + & - & + & + & + & + \\
\hline Nitzschia communis Rabenh. & + & - & - & + & + & - & + & + & + & - & - & - \\
\hline N. hantzschiana & - & - & - & - & - & + & + & - & + & - & - & - \\
\hline N. obtusu & + & - & + & + & - & + & - & - & - & + & + & - \\
\hline N. sigma (Kuetz.) W. Sm. & + & + & - & - & - & + & - & + & + & + & - & - \\
\hline N. vitrea & + & - & - & + & + & - & - & + & - & - & + & + \\
\hline Pinnularia appendiculata & + & - & - & - & + & + & - & - & + & - & + & - \\
\hline P. borealis & - & - & - & + & + & + & - & - & - & + & - & + \\
\hline P. viridis (Nitzsch) Her. & + & - & + & - & - & - & - & + & + & + & + & - \\
\hline Syndera ulna küetz & - & + & + & - & - & - & - & + & - & - & + & + \\
\hline S. affinis küetz & + & - & - & - & - & + & - & + & - & + & - & + \\
\hline
\end{tabular}

S. affinis kuetz

Ten Kilometers within the bed of Wadi-Araba.

** Five Kilometers within Wadi Abu-Khodirate

*** Five Kilometers within Wadi-Irkase.

Table (5). Total number of algal species in soil samples collected from different sites of Wadi-Araba, Egypt (during March, 2003).

\begin{tabular}{|c|c|c|c|c|c|}
\hline \multicolumn{2}{|c|}{ Site } & Cyanophyta & Chlorophyta & Bacillariophyta & $\begin{array}{c}\text { Total number of } \\
\text { species }\end{array}$ \\
\hline \multirow{4}{*}{ 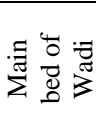 } & Site 1 & 26 & 5 & 17 & 48 \\
\hline & Site 2 & 29 & 4 & 12 & 45 \\
\hline & Site 3 & 21 & 8 & 8 & 37 \\
\hline & Site 4 & 23 & 10 & 9 & 42 \\
\hline \multirow{4}{*}{ 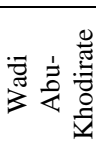 } & Site 1 & 13 & 10 & 8 & 31 \\
\hline & Site 2 & 11 & 9 & 12 & 32 \\
\hline & Site 3 & 14 & 9 & 5 & 28 \\
\hline & Site 4 & 14 & 8 & 14 & 36 \\
\hline \multirow{4}{*}{ 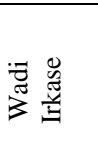 } & Site 1 & 15 & 8 & 12 & 35 \\
\hline & Site 2 & 11 & 11 & 11 & 33 \\
\hline & Site 3 & 13 & 12 & 9 & 34 \\
\hline & Site 4 & 12 & 5 & 9 & 26 \\
\hline
\end{tabular}



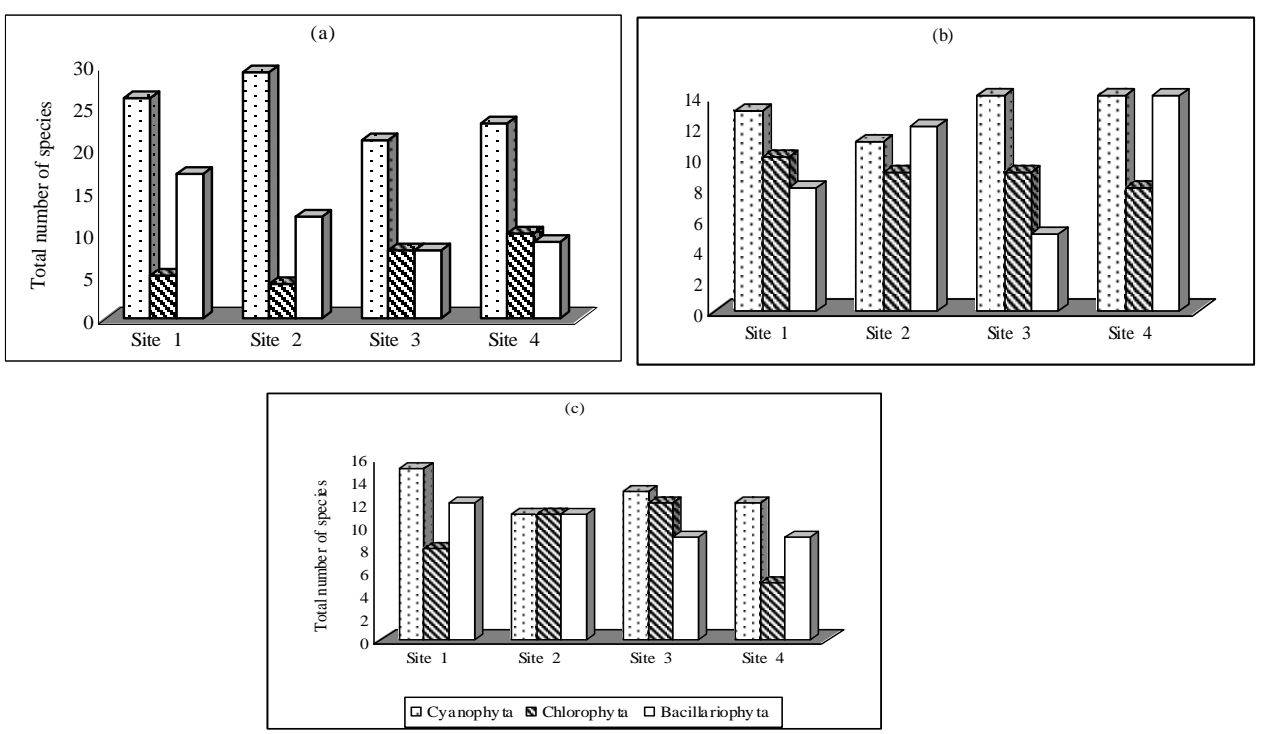

Fig. 3. Composition of microalgal crusts of soil samples collected from the study area of Wadi Araba during March 2003, (a) sites of the main bed of Wadi-Araba, (b), Wadi Abu Khodirate and (c) sites of Wadi Irkase.

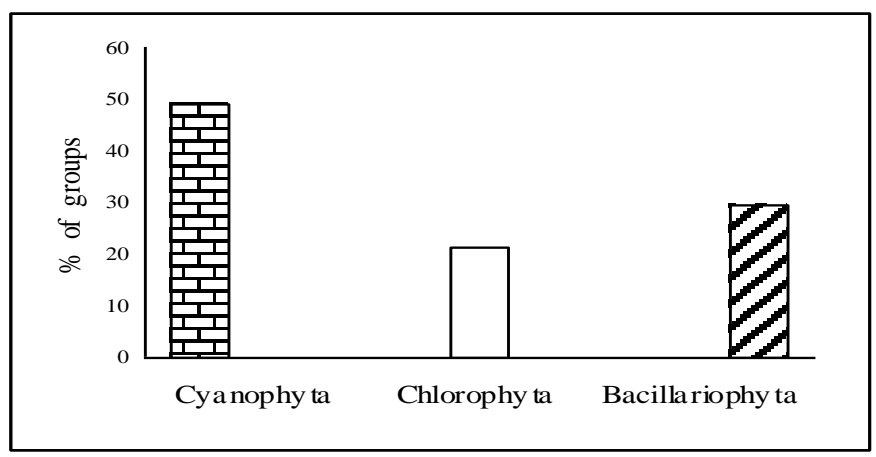

Fig. 4. Percentage of algal groups occupied crusts of the study area of Wadi Araba.

In this respect, Keeling (1974) reported that, the differences of microbiological crusts might be due to quantitative or qualitative differences in root exudates which directly or indirectly influence the quantity and quality of microflora. The chemistry of these root exudates was found to be of various composition.

Among these exudates are alcohols, aldhydes, olefins and volatile organic acids (Vancura and Stotzky, 1971 and Afifi, 1976). The presence of higher number of prokaryotic algae of the total number of species in all tested crusts, accompanied by adequate numbers of nitrogen fixing species could be taken as a common feature for all crusts, a phenomenon which was noticed in other wild 
plants (Schields and Durrell, 1964). The total algal populations encountered during this study were affected by the edaphic factors and physico-chemical characters of the soil sampled, and could be taken as an indication of the presence of a correlation between the various edaphic factors prevailing in the different habitats and the algal occurrence in this stands or sites. It seemed probable that $\mathrm{pH}$ and organic carbon of soil samples are the major controlling factors affecting the growth and distribution of algal populations. The increase or decrease in species number went parallel to these parameters. In this respect, Ketchum, (1951) speculated that the organic matters may have a greater effect on the algae than inorganic nutrients. Also, Sheath and Munawar (1974) discussed the variations in the soil algae which may be limited by eutrophication.

The present investigation revealed that, the majority of algal isolates from all studied sites are related to Cyanophyta. The representative of numerous bluegreens as compared with the other two groups of soil algae is a matter of tolerance and adaptability (Brock, 1973). These organisms were found to flourish under $\mathrm{pH}$ more than 7 (Bold, 1970). The $\mathrm{pH}$ values at all sites under study ranged from 8 to 8.5, and this might partially explain the wide distribution of Cyanophyta compared with the other groups. On the other hand, the wide spread of bluegreens may be due mainly to the cellular structure of such organisms. In this manner, Fay and Fogg (1962) reported that, the ability of Cyanophyta to survive under variable conditions is due to the properties of prokaryotic cells.

Generally, the results of this investigation revealed the presence of moderate abundance of Bacillariophyta. However, site 1 (the main bed of Wadi Araba) and site 4 (Wadi Abu-Khodirate) have the greatest number of diatoms relevant to the other sites. The existence of high percentage of diatom species in these two sites could be attributed to the relatively high $\mathrm{pH}$ values (8.5 and 8.2), high total soluble salts $(0.202$ and $0.30 \%)$ and high silicon contents (39.35 and $20.87 \%$ ). These observations indicate the importance of these three factors in the distribution of diatoms. Such correlation was confirmed earlier by Bock (1963) and later by Kobbia and Shabana (1988) and Ahmed (1994). The results of this investigation indicate the presence of some species of Chlorophyta in all studied sites but in small amounts. The lower abundant of green algae in the investigated sites might be due to the poor content of these sites in their organic materials and the relatively alkaline $\mathrm{pH}$ values, which affect the growth of green algae. This is in accordance with the findings of Bock (1963) and Kobbia \& Shabana (1988).

\section{References}

Abu Al-Izz, M. S. (1971). Landforms of Egypt. Translated by Dr. Yusuf, A. Fayed. The american Univ. in Cairo Press, Cairo, Egypt, 281 pp.

Afifi, A. F. (1976). Volatile and gaseous exudates of either germinating seeds or roots of Okra wilt decease occurred by some Fusarium spp. Abl. Bakt. 131.

Ahmed, Z. A. (1994). Preliminary survey of soil algal flora in Upper Egypt. Egypt. J. Bot. 34, 1, 17-36. 
Allen, M. M. and Stanier, S. T. (1968). Selective isolation of blue-green algae from water and soil. J. gen Microbiol, 51, 203.

Allen, S.; Griwshay, H. M.; Parakinson, J. A. and Quarmby, C. (1974). Chemical analysis of ecological materials (Blackwell; Oxord): pp 565.

Ayyad, M. A. and Ghabbour, S. I. (1986). Hot desert in Egypt and the Sudan. In M. Evenari, I. Noy-Meir and D. W. Goodall (eds.). Hot deserts and Arid Shrublands. Elsevier Sci. Publisher B. V. Amesterdam, 149-202.

Bailey, D.; Mazurak, A. P.; Rushforth, S. R. and Johansen, J. R. (1973). Aggregation of soil particles by algae. J. Phycol. 9:99-101.

Bock, W. (1963). Diatomeen extrem trockener standorte. Nova Hedw., 6, 199254.

Bold, H. C. (1970). Some aspects of the taxonomy of soil algae. Annals of the New York Academy of Scinces, 175, 601.

Boulos, L. (1995). Flora of Egypt Checklist. Al-Hadara Publ., Cairo, Egypt, 283pp. Oikos: 46: $284-291$.

Brock, T. D. (1973). Evolutionary and ecological aspects of the Cyanophytes. 487-500, In N-G. Carr and B.A. Whitton, editors( The Biology of Bluegreen Algae), University of California Press, Berkeley, California, U.S.A.

Cameron, R. E. (1960). Communities of soil algae occurring in the Sonoran Desert in Arizona. J. Arizona Acad. Sci. 1: 85-88.

Cameron, R. E. (1964). Algae of southern Arizona. II. Algal Flora (exclusive of bluegreen algae). Rev. Algolog. 7: 151-177.

Campbell, S. E.; Seeler, J. S. and Glolubic, S. (1989). Desert crust formation and soil stabilization. Arid Soil Res Rehab, 3:317-328

El-Ayouty, A. Y. and Ayyad, M. A. (1972). Studies on blue green algae of the Nile Delta. I. Description of some species in a wheat field. Egypt. J. Bot., $15,283$.

Eldridge, D. J. and Greene, R. S. B. (1994). Microbiotic crusts: a review of their rolesin soil and ecological processes in the rangelands of Australia. Aust J Soil Res, 32:389-415.

El-Hadidi, M. N. and Fayed, A. A. (1995). Materials for excursion Flora of Egypt (EFE). Taeckholmia. 15: (1994 / 95).

El-Nayal, A. A. (1935) Egyptian fresh water algae, Bull. Fac. Sci., 4, 1.

Evans, R. D. and Johansen, J. R. (1999). Microbiotic crusts and ecosystem processes. Crit. Rev. Pl. Sci. 18: 183-225.

Fay, P. and Fogg, G. E. (1962). Studies on nitrogen fixation by blue-green alge. III- Growth and nitrogen fixation in Chlorogoea fritschii Mitra. Arch. Mikrobiol., 42, 310-21.

Friedmann, I.; Limpkin, Y. and OcampoPaus, R. (1967). Desert algae of the Negev (Israel). Phycologia 6: 185-196.

Gee, G. W. and Bauder, J. W. (1986). Particle size analysis. P 383 - 411. In : Methods of soil analysis. In Part \& A. Klute (ed.). Agronomy series No. 9 Am. Soc. Agronomy and Soil Sci. Soc. Am. Inc., Publ., Madison, W. I. 
Hawkes, C. V. and Flechtner, V. R. (2002). Biological soil crusts in xeric Florida Shrubland: composition, abundance, and spatial Heterogeneity of Crusts with Different Disturbance Histories. Microb Ecol., 43:1-12.

Jackson, M. L. (1958). Soil chemical analysis. Printice-Hall, Inc., Englewood, Cliffs, NJ.

Johansen, J. R. (1993). Cryptogamic crusts of semiarid and arid lands of North America. J Phycology, 29: 140-147.

Jurgensen, M. F. and Davey, C. B. (1968). Nitrogen fixing blue-green algae in acid forest and nursery soils. Can. J. Microbiol. 14, 1179.

Keeling, B. L. (1974). Soyabeen seed rot and the relation of seed exudate to host susceptability. Pathology, 64, 1445.

Ketchum, B. H. (1951). Plankton algae and their biological significance. In Manual of Phycology, (G.M. Smith, Ed.). Waltham, Mass.: Chronica Botanica Co., 335-346.

Kleiner, E. F. And Harper, K. T. (1977). Soil properties in relation to cryptogamic ground cover in Canyonlands National Park. J Range Management, 30:202-205.

Kobbia, I. A. (1983). Ecophysiological studies on the rhizosphere algae of some Egyptian plants. Egypt Sco. Of Appl. Microbiol. Proc. V., Conf. Microbial., Cairo, 2 Soils and Water Microbiol. Paper No. 49, 143-166.

Kobbia, I. A. (1985). Nitrogen-fixing blue green algae of the semiarid regions along the gravel and limestone deserts of Cairo-Suez Road, Egypt. Sohag, Pure and Appl. Sci. Bull., Fac. Sci., Egypt, 2, 15.

Kobbia, I. A. and El-Batanony, K. H. (1975). Studies on the algal flora of Egyptian soils. I. Different sites along a tricklet of a lake in the salines of Wadi-ElNatroun, Publ. Cairo University, Herb, 6, 61.

Kobbia, I. A. and Shabana, E. F. (1988). Studies on the soil algal flora of Egyptian Bahariya Oasis. Egypt. J. Bot. 31, 1-3, 23.

Lange, O. L.; Kidron, G. J.; Büdel, B.; Meyer, A.; Kilian, E. and Abeliovich, A. (1992). Taxonomic composition and photo-tosynthetic characteristics of the "biological soil crusts" covering sand dunes in the western Negev Desert. Funct. Ecol. 6: 519-527.

Lewis, L. A. and Flechtner, V. R. (2002). Green algae (Chlorophyta) of desert microbiotic crusts: diversity of North American taxa. Taxon . 443-451.

Li, X. R.; Wang, X. P. and Zhang, J. G. (2002). Microbiotic soil crust and its effect on vegetation and habitat on artificially stabilized desert dunes in Tengger Desert, North China. Biol Fertil Soil.,147-154.

Loveday, J. (1974). Methods of analysis of irrigated soils. Bureau of soils and technical communication, no. 54. Commonwealth.

Lund, J. W. G. (1967). Soil algae. In Soil Biology, A. Burges and F. Ram, eds, P. 129-148, London, Academic Press. 
Nichols, H. W. (1973). Growth media- fresh water in . J. R. Stein, editor (Handbook of phycological methods) Cambridge Univ. Press. New York, U. S. A., pp, 7-24.

Piper, C. S. (1944). Soil and plant analysis. A laboratory manual of methods for the examination of soils and the determination of inorganic constituents of plants. A monogr. From the Water Agri. Res. Inst. , Univ. of Adelaide, Adelaide.

Piper, C. S. (1950). Soil and plant analysis. A monogr. From the Water Agri. Inst. Univ. of Adelaide, Adelaide.

Prescott, G.W. (1951).Algae of the Western Green Lakes area. Exclusive of desmids and diatoms. Bull. No. 31, Cranbrook Inst. Of Scie.

Prescott, G. W. (1969). The algae. A review. Michigan State Univ., Butler \& Tanner Ltd, Frome and London.

Prescott, G.W. (1978). How to know the freshwater algae. $3^{\text {rd }}$ Ed. Wm. C. Brown Company Publishers. USA.

Riley, G. A. (1967). Phytoplankton of Long Isoland Sound. Bull. Bingh. Oceangi Cell, 19: 5-34.

Salama, A. M. and Kobbia, I. A. (1982). Studies on the soil algal flora of Egyptian soils. II. Different sites of a sector in the Lybian Desert, Egypt. J. Bot. 25,139.

Schields, L. M. and Durrell, L. W. (1964). Algae in relation to soil fertility. Bot. Review, 30, 92-128.

Schlesinger, W. H.; Raikes, J. A.; Hartley, A. E. and Cross, A. E. (1996). On the spatial pattern of soil nutrients in desert ecosystems. Ecology. 77: 364374.

Sheath, R. and Munawar, M. (1974). Pytoplankton composition of a small subarctic lake in the Northwest Territories, Canada. Phycologia, 13, 149.

Shields, L. M. and Drouet, F. (1962). Distribution of terrestrial algae within the Nevada Test Site. Amer. J. Bot. 49: 547-554.

Skujinš, J. (1984). Microbial ecology of desert soils. In: Marshallš CC Advances in Microbial Ecology, vol 7. Plenum Press, New York, 49-91.

Soil Survey Staff (1972). Soil survey laboratory metods and procedures for collecting soil samples. Soil survey investigation report. 1. U.S.D.A. , S.C.S. U.S Gover. Printing Office, Washington, D. C.

Smith, G. M. (1933). The fresh-water algae of the united states. $1^{\text {st }}$ Ed. McGrawHill B. Comp, Inc. New York and London.

Smith, G. M. (1951). The fresh-water algae of the united states. $2^{\text {nd }}$ Ed. McGraw-Hill Book Company, Inc. New York, Toronto, London.

St. Clair, L. L.; Johansen, J. R. and Rushforth, S. R. (1993). Lichens of soil crust communities in the Intermountain Area of the western United States. Great Basin Natur. 53.

Standard Methods For The Examination of Water and Wastewater (1985). 16th Ed. AWWA-WPCE-APHA. 
Tan, K. H. (1996). Soil sampling, preparation and analysis. Marcel Dekker, Inc., New York, NY.

UNESCO (1977). Map of the world distribution of Arid regons. Map Technical Notes, 7.

Walkely, A. (1947). A critical examination of a rapid method for determining organic carbon in soil : effect of variation in digition conditions and inorganic soil constituents. Soil Sci. 63:251-263.

West, N. E. (1990). Structure and function of microphytic soil crusts in wildland ecosystems of arid to semi-arid regions. Adv. Ecol. Res. 20: 179-223.

Vancura, V. and Stotzky, G. (1971). Excretion of germinating plant seed . Folia Microbiol. 16, 512.

Zahran, M. A. and Willis, A. J. (1992). The vegetation of Egypt. Chapman and Hell. Pub. London.

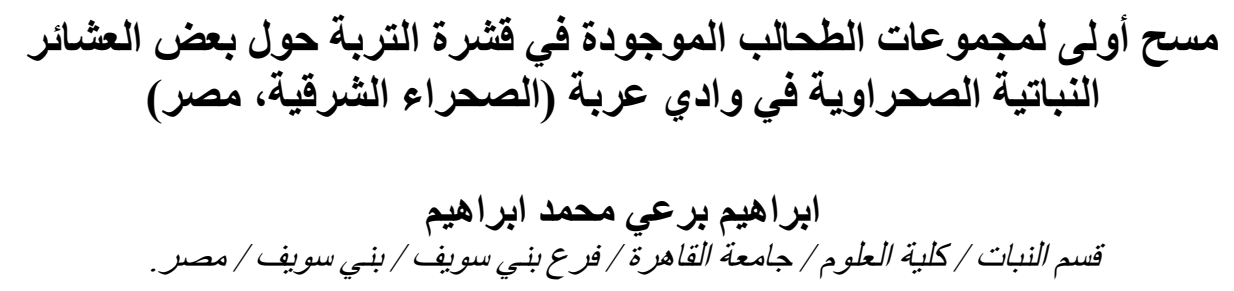

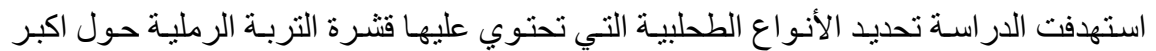

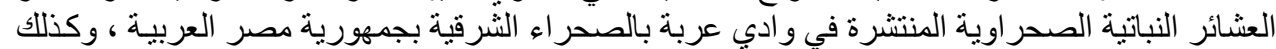

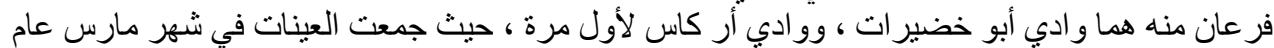

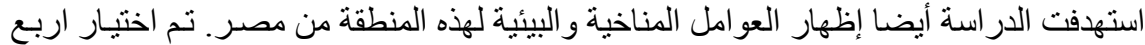

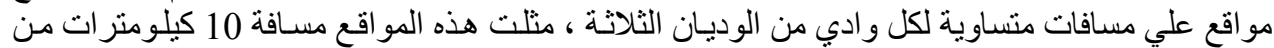

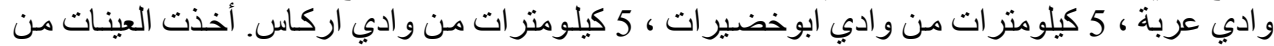

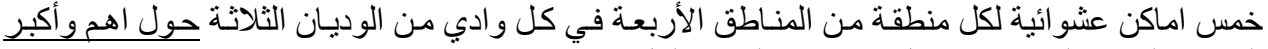
العشائر النباتية المنتشرة في كل موقع من المو اقع لكل وادي.

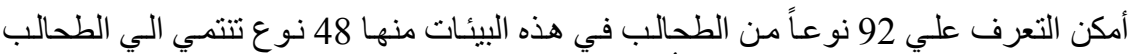

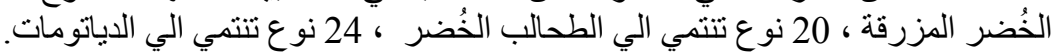

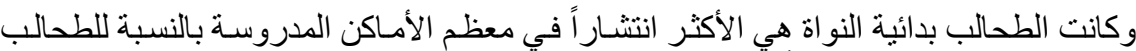

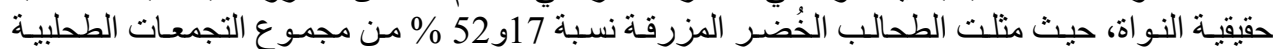

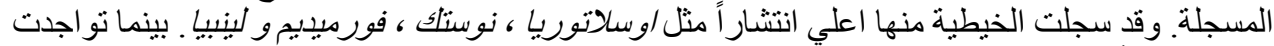

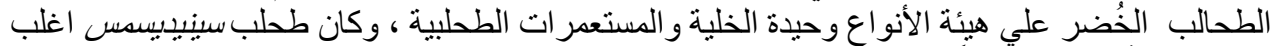

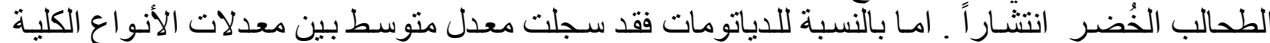

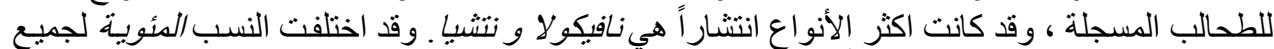

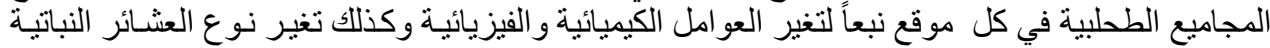

